\title{
Efficacy and safety of galantamine in the treatment of Alzheimer's Disease and Alzheimer's Disease with cerebrovascular (Mixed Dementia) (GAL-DEM-402)
}

\author{
S.F. Lumempouw, J. Misbach, N. Diatri
}

\begin{abstract}
Abstrak
Penelitian ini bertujuan menilai efektivitas dan keamanan Acetylcholinesterase Inhibitor Galantamine pada penderita Alzheimer dan Alzheimer's Disease (AD) yang disertai dengan penyakit serebrovaskular (AD+CVD atau Mixed Dementia). Galantamine diberikan selama 6 bulan pada 28 penderita $A D$ dan $A D+C V D$. Evaluasi kognitif dilakukan dengan menggunakan Mini Mental State Examination (MMSE), Restricted Reminding (RR), Neuropsycholgy Assessment, evaluasi fungsi global dengan Clinical Dementia Rating (CDR), evaluasi perubahan perilaku dengan Neuropsychiatric Inventory (NPI). Hasil penelitian pada 28 penderita AD dan AD $+C V D$, Galantamine memberikan perbaikan fungsi kognitif yang bermakna secara klinis maupun statistik setelah terapi 6 bulan dibandingkan data dasar awal (skor MMSE p<0.05, skor RR p<0.05, NA p<0.05), perbaikan fungsi global (CDR p<0.05) dan perbaikan gejala perilaku (NPI p<0.05). Efek samping ringan (32\%) mual-mual dan anokresia terjadi saat titrasi dosis obat dan dapat diatasi dengan domperidone. Disimpulkan bahwa Galantamine efektif memberikan perbaikan fungsi kognitif, fungsi global, gejala perilaku dan aman serta dapat ditoleransi dengan baik. (Med J Indones 2007; 16:94-100)
\end{abstract}

\begin{abstract}
This study was aimed to evaluate the efficacy and safety of Acetylcholinesterase Inhibitor Galantamine (Reminyl $\left.{ }^{\circledR}\right)$ for patients with Alzheimer's Disease (AD) and Alzheimer's Disease with cerebrovascular Disease (AD+CVD or mixed Dementia). A 6-month open label observational study of Galantamine has been conducted on 28 patients with $A D$ and $A D+C V D$ patients. Primary endpoints were cognitive performance as assessed using the Mini Mental Scale Examination (MMSE), the Restricted Reminding Test), the Neuropsychology Assessment, the Clinical Dementia Rating (CDR) to assess global function and the Neuropsychiatric Inventory (NPI) to assess behavioral symptoms. Patients were also monitored for safety evaluation. Six month Galantamine group had a significant better outcome of cognitive performance, global function and behavioral symptoms compared with the baseline data as were assessed using the MMSE ( $p<0.05)$, the Restricted Reminding ( $p<0.05)$, the Neuropsychology Assessment $(p<0.05)$, the CDR ( $p<0.05)$ and the NPI ( $p<0.05)$. Minimal adverse events (32\%) were anorexia and nausea. It is concluded that Galantamine has a significant benefit to improve cognitive, global function, behavioral symptoms and only caused minimal adverse events. (Med J Indones 2007; 16:94-100)
\end{abstract}

Keywords: Galantamine, alzheimer, cerebrovascular disease, dementia, $A D, A D+C V D$

Alzheimer disease (AD) is a progressive, neurodegenerative disorder characterized by a loss of memory and cognition, inability to perform activities of daily living, and changes in personality and behavior.

Symptomatic treatment of AD is currently based on the cholinergic hypothesis, which states that many of the cognitive, functional, and behavioral symptoms derived from a reduction in brain acetylcholine

Department of Neurology, Faculty of Medicine University of Indonesia/Dr. Cipto Mangunkusumo General Hospital, Jakarta, Indonesia activity secondary to the loss of cholinergic neurons in the nucleus basalis of Maynert and other nuclei projecting to the hippocampus and mesial temporal region $^{1}$

AD is the most common cause of dementia, and Vascular Dementia is the second common form of dementia. The differentiation between $\mathrm{AD}, \mathrm{VaD}$, and $\mathrm{AD}$ with cerebrovascular disease (AD+CVD; also known as mixed dementia) is complicated by symptom overlap and lack of well-defined diagnostic criteria. The AD+CVD prevalence rates from autopsy studies vary widely (2-36\%), and those from clinicopathologic studies are even higher $(18-60 \%)^{2}$ 
The underlying cause of cognitive decline in $\mathrm{VaD}$ (and, therefore, $\mathrm{AD}+\mathrm{CVD}$ ) appears cholinergic dysfunction, as with $\mathrm{AD}$. It is reasonable to expect that acetylcholinesterase inhibitor may be useful in patients with $\mathrm{AD}+\mathrm{CVD}$.

Galantamine $\left(\right.$ Reminyl $^{\circledR}$ ), a novel cholinergic agent with a unique dual mode of action (an acetylcholinesterase inhibitor and allosteric modulator of nicotinic receptors), has consistently demonstrated broad benefits on cognition, global function, activities daily living (ADL). In addition to inhibiting acetylcholinesterase, galantamine allosterically modulates neuronal nicotinic receptors. This additional mechanism of action amplifies the actions of acetylcholine (Ach) at pre and postsynaptic nicotinic Ach receptors and, in particular, modulates the release of Ach and other neurotransmitters such as glutamate, serotonin, dopamine and GABA. ${ }^{3}$

Randomized clinical trials of Galantamine have shown efficacy on global impression, cognition, ADL, and behavior. $^{4-6}$ There is evidence of some cognitive benefit to patients with mixed Alzheimer's disease and cerebrovascular disease. Slow dose escalation appears to improve tolerability to the drug. ${ }^{7-10}$

The efficacy outcomes for patients with AD+CVD after 12 months treatment of Galantamine, scores remained near baseline level. ${ }^{10}$

Cognitive scores of patients AD treated with Acetylcholineesterase Inhibitors Galantamine over a period of 6 months, 16 and $24 \mathrm{mg}$ /day maintained patients' cognitive function above baseline, fall below baseline after 12 months, and experienced appreciably less cognitive decline over 24 months than that seen in placebo control group. ${ }^{11}$

Adverse events were typically mild as results in all double blind, placebo controlled trials. ${ }^{4,5,7}$

Recent data have shown that Galantamine improves the early signs of neurodegeneration and reduces amyloid precursor protein vascular deposition in anti nerve growth factor mice. ${ }^{23}$

This is the first study of acetylcholinesterase Inhibitor in subject with $\mathrm{AD}$ and $\mathrm{AD}+\mathrm{CVD}$ (Mixed Dementia) to evaluate the efficacy and tolerability of galantamine, $16 \mathrm{mg} /$ day-known protocol GAL-DEM-402 in Indonesia.

\section{METHODS}

Patients. Patients with Alzheimer's disease and Mixed Dementia were recruited from Neurobehavior outpatient clinic of Department of Neurology Cipto Mangunkusumo Hospital Jakarta, from January 2004 until July 2005.

Patients who met all of the following criteria were eligible for this trial.

1. Male/female outpatient with $A D$ and $A D+C V D$ as detailed in the National Institute of Neurological and Communicative Diseases and Stroke/Alzheimer's Disease and Related Disorders Association (NINCDS-ADRDA) ${ }^{12}$ criteria with modification.

2. No disturbance of consciousness, absence of systemic disorders or other brain diseases (except $\mathrm{AD}$ and cerebrovascular disease) that could account for the dementia.

3. Radiologic évidence (satisfying the NINDSAIREN radiologic criteria / National Institute of Neurological Disorders and Stroke-Association Internationale pour la Recherche et l'Enseignement en Neurosciences) $)^{14}$ as documented on a CT or MRI scan not older than 12 months.

4. Mild/moderate dementia as evidenced by a MiniMental State Examination score (MMSE) ranging from10-25, Hachinski Ischemic Score < 4: Alzheimer Dementia and score $\geq 4$ Mixed Dementia

5. Patients had a responsible caregiver, or appropriate representative.

Patients were excluded from the study if they had evidence of any other neurodegenerative disorders; any cognitive impairment.

Patients with the following co-existing medical conditions were also excluded: Any history of epilepsy, current clinically significant psychiatric disease as judged by DSM-IV criteria, history of drug or alcohol abuse, active peptic ulcer, clinically significant hepatic, renal and pulmonary disturbances, urinary outflow obstruction, cardiovascular disease that would be expected to limit the patient's ability to complete a 6 months trial, history of severe drug allergy or hypersensitivity. Any agent used for the treatment of dementia may not be used after enrolment in this trial. Note: Acetyl Salicylic Acid taken in doses up to $325 \mathrm{mg}$ daily and anti-hypertensive to prevent cardio- or cerebrovascular disease, does not exclude the patient. 
Patient also excluded from the trial if they withdraw their consent or the caregiver(s) withdraw the consent.

Screening assessment: Mini Mental State Examination (MMSE) to exclude severe dementia, Hachinski Ischemic Score (HIS) ${ }^{15}$ to assess mixed dementia. Strub \& Black Mental Test Neurology ${ }^{16}$ to assess cognitive function, TOKEN test ${ }^{17}$ to exclude sensoric aphasia. Tes Afasia untuk Diagnosis Informasi Rehabilitasi (TADIR) ${ }^{18}$ to exclude severe aphasia. Written informed consent was obtained from family of all patients, and the experimental protocol was approved by the Ethics Committee of Medical Faculty, University of Indonesia.

This study was 6-month open-label clinical. Patients will receive $4 \mathrm{mg}$ bid galantamine for the week 1-4; from week 5 onward subjects will receive $8 \mathrm{mg}$ bid galantamine.

Efficacy Assessments. The efficacy will be evaluated on the first time patients taking the drug, the end of 1 , 3 , and $6^{\text {th }}$ month.

- Mini Mental State Examination (MMSE) to evaluate cognitive function

- Restricted Reminding (RR) to evaluate verbal memory, modification from Buschke Selective Reminding Test (SRT) ${ }^{19}$

- Neuropsychology Assessment (NA) to evaluate cognitive function, modification from CERAD (The Consortium to Establish a Registry for Alzheimer's Disease) ${ }^{20}$

- Clinical Dementia Rating (CDR) to evaluate global function $^{21}$

- Neuropsychiatric Inventory (NPI) to evaluate behavior symptoms ${ }^{22}$

MMSE, CDR and NPI are standard assessment used in many literatures and international trials.

Safety Assessments. Safety evaluations were performed throughout the study and included vital sign, electrocardiography (ECG), standard clinical laboratory tests, and physical examination. Adverse events were monitored throughout each study period.

The data were analysed using descriptive statistics and graphical representations.

\section{RESULTS}

Based on 18 month screening examination, there were 50 dementia patients, 28 patients were eligible for the study, appropriate to inclusion and exclusion criteria,
2 patients were only had 2 month treatment and subsequently rejected to continue treatment, therefore there were 26 patients who completed the 6 month treatment study.

Patient medical and demographic characteristics are summarized in Table 1. Among 28 patients, 19 (67\%) were $\mathrm{AD}$ and $9(33 \%)$ were mixed dementia. Mild dementia patients were found in $13(46 \%)$ of patients and moderate dementia in $15(54 \%)$ of patients.

Table 1. Baseline characteristic

\begin{tabular}{cccccccc}
\hline \multicolumn{2}{c}{ Sex } & \multicolumn{2}{c}{ Age (year) } & \multicolumn{2}{c}{ Diagnose } & \multicolumn{2}{c}{ Dementia } \\
\hline Male & Female & Interval & Mean & AD & AD & Mild & Moderate \\
& & & & & + & (MMSE & (MMSE \\
& & & & & CVD & $21-25)$ & $10-20)$ \\
12 & \multirow{2}{*}{16} & $47-93$ & 68,9 & $19 / 28$ & $9 / 28$ & $13 / 28$ & $15 / 28$ \\
\hline
\end{tabular}

The mean value of cognitive MMSE domains of patients: orientation was 6.1 (total score 10), registration was 3 (total score 3 ), attention was 2.9 (total score 5), recall memory was 0.5 (total score 3 ), language was 7.9 (total score 8), and dementia patient with MMSE interval 14-25. The mean NPI value was 4.18 and the mean CDR value was 1.05.

In cognitive evaluation by using Neuropsychology Assessment, the mean value for attention was 5.07, which was within the normal limit, for memory was 3.64 (total score 10), form naming was 12.07 (total score 15), for verbal fluency was 7.50 (normal value for elderly was >10), for visuoconstruction was 7.07 (total score 11), for memory recall was 0.75 (total score 10) and for recognition memory was 3.75 (total score 10).

\section{Cognition}

In evaluation of cognitive function by using MMSE, there was significant difference from baseline data since the 2nd month evaluation (Figure.1).

The 6-month Galantamine had a significantly better outcome of cognitive performance, comparable with the baseline data as were assessed using the MMSE $(p<0.05)$, the Restricted Reminding $(p<0.05)$; the Neuropsychology Assessment $(p<0.05)$

On figure 2, after 6-month treatment, the evaluation on MMSE cognitive domain indicated a better result, which included: orientation, attention, calculation, memory recall and language. 


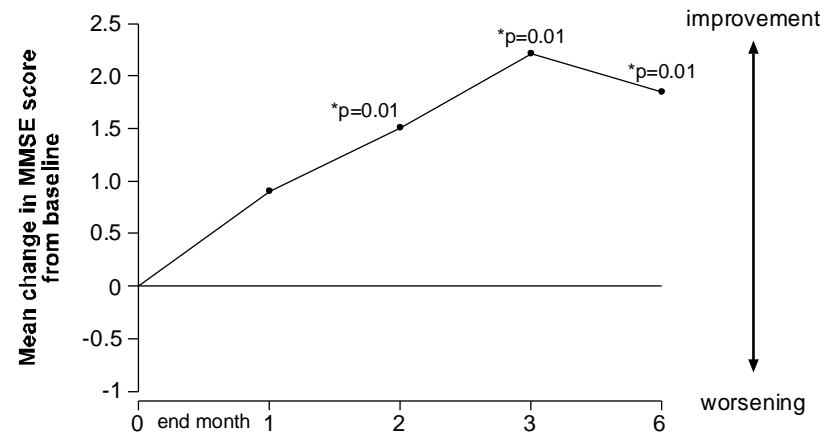

Figure 1. Evaluation of MMSE

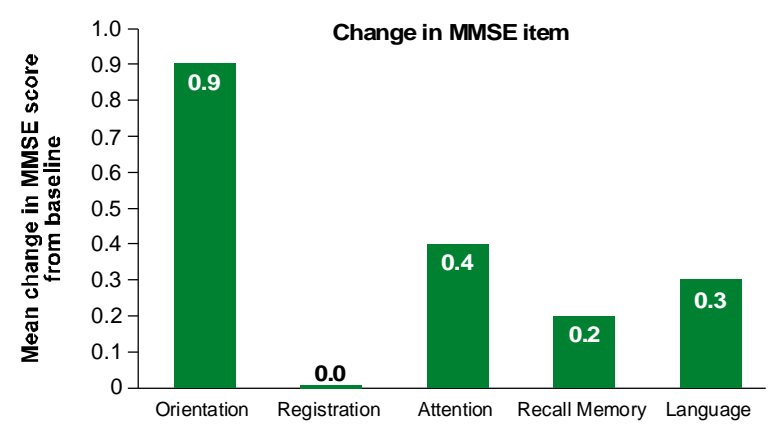

Figure 2. Evaluation of cognitive domains from MMSE

Verbal memory has indicated significant difference from baseline data since initial evaluation in last $1^{\text {st }}$ month (Figure 3). Moreover, the evaluation of Neuropsychology Assessment (NA) total score has been also significantly different (Figure 4). In the end of $6^{\text {th }}$ month, the domains of NA, which significantly indicated better result, were: reason memory, verbal fluency, recalls memory and recognition (Figure 5)

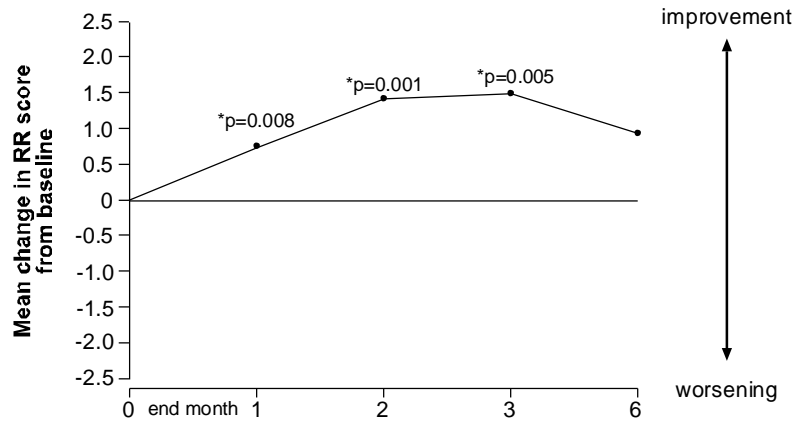

Figure 3. Evaluation of verbal memory test

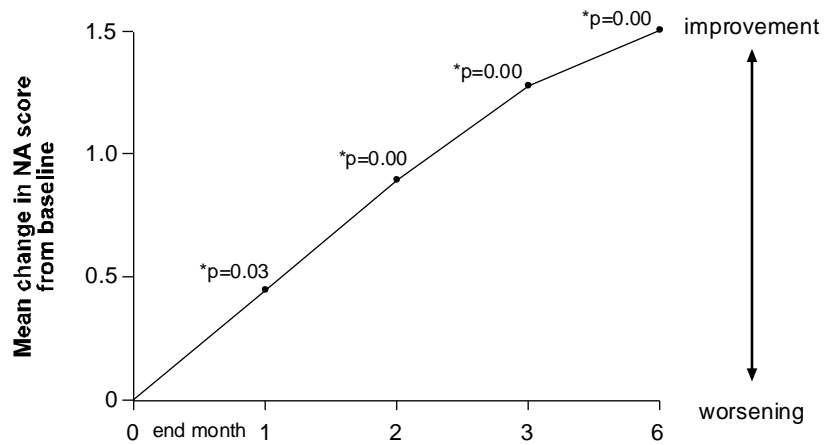

Figure 4. Evaluation of NA.

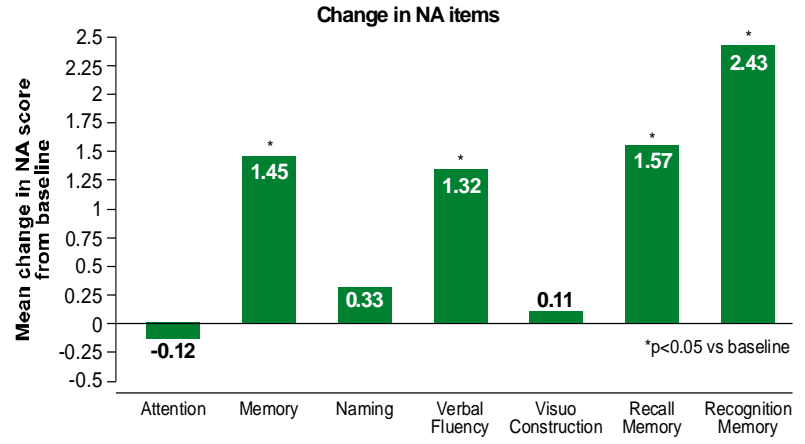

Figure 5. Evaluation of cognitive domains from NA

\section{Global function}

Initially at the end of $2^{\text {nd }}$ month, Clinical Dementia Rating (CDR) evaluation was significantly different compared to baseline. The 6-month Galantamine had better significant outcome of global function, with CDR $(p<0.05)$ (Figure 6).

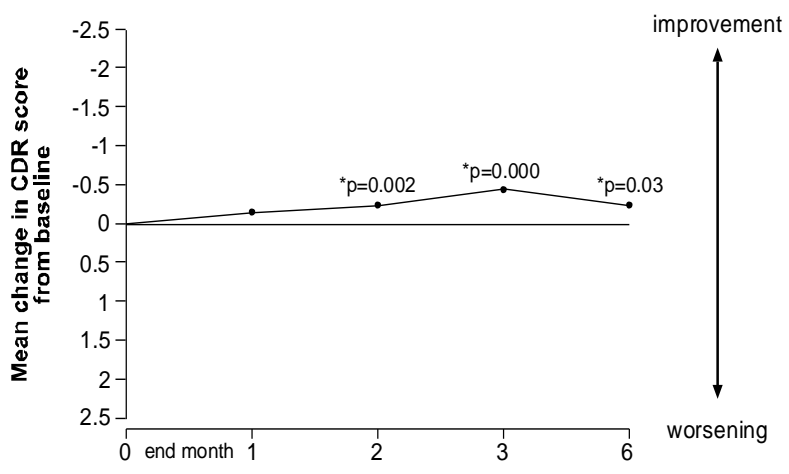

Figure 6. Evaluation of CDR. 


\section{Behavior}

Initially at the end of $2^{\text {nd }}$ month, neuropsychiatry inventory(NPI) evaluation was significantly different compared to the baseline. The 6-month Galantamine had a significant better outcome of behavior changes, the NPI $(p<0.05)$ (Figure 7).

Non-cognitive symptoms improved significantly on NPI after 6-month treatment was: anxiety, apathy, irritability and night-time behavior (Figure 8).

\section{Safety and Tolerability of Galantanine}

Adverse event was found in 9 of 28 patients, 7 patients with nausea and 4 patients with anorexia. Adverse event were typically mild and transient, related to dose escalation, with duration less than 1 week.

\section{DISCUSSION}

This study is the first efficacy \& safety study of acetylcholinesterase inhibitor in $\mathrm{AD}$ and mixed Dementia in Indonesia.

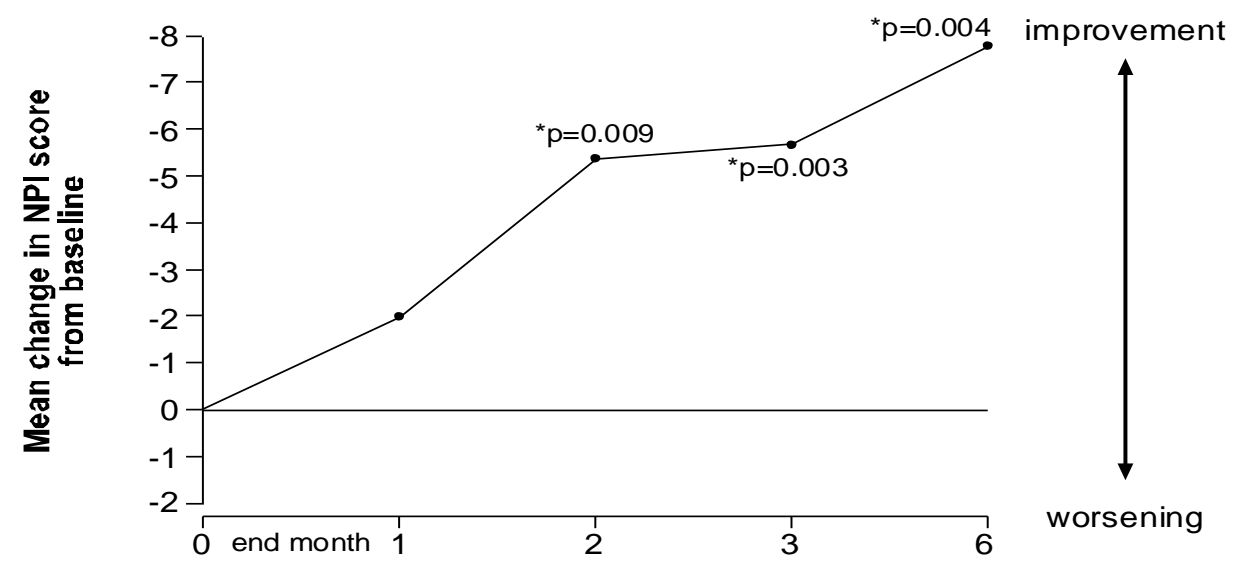

Figure 7. Evaluation of NPI

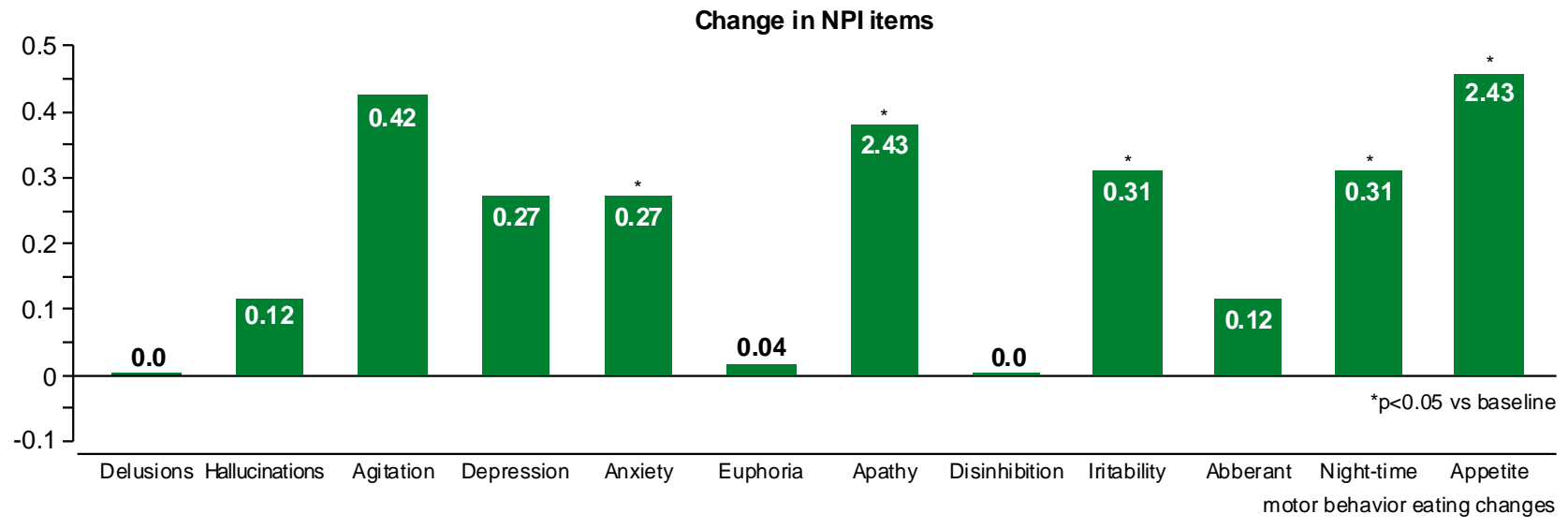

Figure 8. evaluation on NPI non-cognitive domains after 6-month treatment 
This study was limited to its small sample size, therefore no randomization and no control in this study. It is due to few patients with dementia who come to outpatient clinic in Department of Neurology, Cipto Mangunkusumo Hospital, i.e. about 3-5 patients/month. With tight inclusion and exclusion criteria during 18 months observation, there were only 50 dementia patients accumulated, but only 28 patients were eligible for the study, 2 patients did not continue the treatment because of moved living town. Therefore, there were only 26 cases, which completed the 6-month treatment study.

There are $67 \%$ patients with $\mathrm{AD}$ and $33 \%$ patients with $\mathrm{AD}+\mathrm{CVD}$, which is similar to the prevalence of VAD (AD+CVD) by Jellinger study ${ }^{2}$. Progressive deterioration in cognitive function, particularly memory, is the defining feature of Alzheimer's disease. Nevertheless, other characteristic aspects of the disease, such as global function and behavioral disturbances are of great importance, particularly for sufferers and their careers.

Current study showed that result in cognitive evaluation with MMSE after 6 month had a significant improvement at: orientation, attention/ calculation, memory recall and language function. Special memory test of RR showed earlier amelioration after 1 month, and so do at total scores of NA after 6 month; all tests of memory at NA (reason memory, recall memory, and recognition memory) significantly amelioration above baseline.

The result of this sub analysis showed that Galantamine $\left(\right.$ Reminyl ${ }^{\circledR}$ ) is effective in treating the symptoms of memory loss in patients with AD and AD+CVD.

The assessment of global function and behavior alteration indicated significant improvement at the end of $2^{\text {nd }}$ month evaluation. Therefore, Galantamine effectively improves the global function and behavior alteration not only in $\mathrm{AD}$ patients but also in $\mathrm{AD}+\mathrm{CVD}$ patients.

The adverse events related to the drugs, which occurred after 4-week drug titration is mild, i.e. nausea and anorexia in 9 of 28 cases, and consistent with international data.

The adverse event variation is less than adverse event in previous study. It may be caused by the smaller sample size.
It is concluded that 6 months treatment with galantamine results in significant improvement of cognitive function, memory verbal, behavior symptoms, and global function.

Adverse events were typically mild and transient.

\section{Acknowledgements}

Many thanks are directed to Prof.J Cummings for his kindness to use his Neuropsychiatric Inventory Assessment (NPI) on this study.

\section{REFERENCES}

1. Cummings JL, Vinters HV, Cole GM, et al. Alzheimer's disease: etiologies, pathophysiology, cognitive reserve, and treatment opportunities. Neurology. 1998; 51 (suppl), S2-17.

2. Jellinger KA: Alzheimer disease and cerebrovascular pathology: An update. J Neural Transm. 2002; 109:813-36.

3. Albuquerque EX, Alkondon M, Pereira EFR, et al. Properties of neuronal nicotinic acetylcholine receptors: pharmacological characterization and modulation of synaptic function. J Pharmacol Exp Ther. 1997; 280:1117-36.

4. Raskind MA, Peskind ER, Wessel T, et al. Galantamine in $\mathrm{AD}$ : A 6-month randomized, placebo-controlled trial with a 6-month extension. Neurology. 2000; 54:2261-68.

5. Tariot PN, Solomon PR, Morris JC, et al. A 5-month, randomized, placebo-controlled trial of galantamine in AD. Neurology. 2000; 54:2269-76.

6. Wilcock G, Howe I, Coles H, et al. A long-Term Comparison of Galantamine and Donepezil in the Treatment of Alzheimer's Disease. Drug Aging. 2003; 20(10): 777-89.

7. Erkinjuntti T, Kurtz A, Gauthier S, et al. Efficacy of galantamine in probable vascular dementia and Alzheimer's disease combined with cerebrovascular disease: a randomised trial. The Lancet. 2002; 359:1283-90.

8. Maelicke A. The pharmacological rationale for treating vascular dementia with galantamine $\left(\right.$ Reminyl $\left.^{\circledR}\right)$. Int J Clin Pract. 2001; 120:24-28.

9. Blesa R. Galantamine: Therapeutic Effects beyond Cognition. Dement Geriatr Cogn Disord 2000. 11(suppl 1) 28-34.

10. Bullock R, Erkinjutti T, Lilienfeld S, et al. Management of Patients with Alzheimer's Disease plus Cerebrovascular Disease: 12-Month Treatment with Galantamine. Dement Geriatr Cogn Disord. 2004:17:29-34.

11. Doody R, Truyen L, Hammond G. The benefits of galantamine are maintained for at least 2 years. Poster presented at the $1^{\text {st }}$ Congress of the European Union Geriatric Medicine Society, Paris, France, 29August-1 September 2001.

12. McKhann G, Drachman D, Folstein M, et al. Clinical diagnosis of Alzheimer's disease: report of the NINCDSADRDA Work Group under the auspices of Department of Health and Human Services Task Force on Alzheimer's disease. Neurology. 1984; 34:939-44. 
13. Folstein MF, Folstein SE, McHugh PR. "Mini-Mental State". A practical method for grading the cognitive state of patients for the clinician. J Psychiatr Res. 1975; 12: 189-98

14. Roman GC, Tatemichi TK, Erkinjuntti T, Cummings JL, et al. Vascular dementia: Diagnostic criteria for research studies. Report of the NINCDS-AIREN International Workshop. Neurology. 1993; 43: 250-60.

15. Hachinski VC, Iliff LD, Phil $\mathrm{M}$ et al. Cerebral blood flow in dementia. Arch Neurol. 1975: 32; 632-7.

16. Strub RL, Black FW: The Mental Status Examination in Neurology $4^{\text {th }}$ Ed. F.A.Davis Company, Philadelphia USA, 2000.

17. De Renzi E, Vignolo L. The Token Test: A sensitive test to detect receptive disturbances in aphasics. Brain. 1962;85:665-78.

18. Reni I.I Dharmaperwira-Prins. Tes Afasia untuk Diagnosis Informasi Rehabilitasi (TADIR), 2000.

19. Buschke Selective Reminding Test (SRT) in A Compendium of Neuropsychological Tests: Administration,
Norms, and Commentary $2^{\text {nd }}$ Ed. Spreen O, Strauss E (Eds). Oxford University Press. 1998: 282-95.

20. Welsh KA, Butters N, Mohs RC, et al. The Consortium to Establish a Registry for Alzheimer's Disease (CERAD). Neurology. 1994; 44:609-14

21. Huges CP, Berg L, Danziger WL, et al. A new clinical scale for the staging of dementia in Management of Dementia. Lovestone S, Gauthier S (Eds). Martin Dunitz Ltd.2001; 146.

22. Cummings JL, Mega M, Gray K, et al. The Neuropsychiatric Inventory: comprehensive assessment of psychopathology in Dementia. Neurology. 1994; 44: 2308-14.

23. Capsoni S, Giannotta S, Cattaneo A. Nerve growth factor and galantamine ameliorate early signs of neurodegeneration in anti-nerve growth factor mice. Proc Natl Acad Sci USA 2002; 99:12432-7.

24. Rockwood K, Mintzer J, Truyen L, et al. Effect of a flexible galantamine dose in Alzheimer's disease: a randomized, controlled trial. J Neurol Neurosurg Psychiatry. 2001; 71:5895-95 